\title{
MODEL UJIAN NASIONAL BERBASIS KOMPUTER: MANFAAT DAN TANTANGAN
}

\section{COMPUTER-BASED NATIONAL EXAM MODEL: ITS BENEFITS AND BARRIERS}

\author{
Rogers Pakpahan \\ Pusat Penilaian Pendidikan, Balitbang, Kemdikbud \\ Jalan Gunung Sahari Raya No 4 Jakarta \\ e-mail: ropakpakro@yahoo.com
}

Naskah diterima tanggal: 04/12/2015, Direvisi akhir tanggal: 03/02/2016, disetujui tanggal: 14/03/2016

\begin{abstract}
The purpose of this writing was to review, analyze, and discover the barriers of the implementation of the National Computer-Based Exam. The methodology used was qualitative method with descriptive analysis of the relevant studies and monitoring results of national examinations. The study results show that computer-based test can be implemented in all areas or educational unit when supported by computers and the internet. In order to implement it properly, the schools or educational units must set up the computer hardware, the Internet network and local network computers. The study also reveals that it is saving the printing costs, the security of the script, facilitating the distribution of exam materials, easy to reach the entire area, security, easy to score of the scoring process, and it is possible to print the certificate of test results after completing the exam. The barriers of implementing this model include a wide area or vast territory, computer hardwares, internet facilities, and the support of stakeholders. However, the implementation of computerbased national examinations can be carried out across the region in line with advances in technology information. It conclusion, the implementation of on line computer-based national examinations within a limited area either district/city, provincial, and national levels will shorten the chain of implementation of national examinations that benefits the stakeholders. In addition, implementing online computer based examination enables them to immediately obtain the result after the implementation of the test.
\end{abstract}

Keywords: computer-based test, online national examination, paper-based test, model examanition, information technology

\begin{abstract}
Abstrak: Tujuan penulisan artikel ini adalah untuk mengkaji, menganalisis, dan menemukan hambatan pelaksanaan Ujian Nasional Berbasis Komputer (UNBK). Metodologi yang digunakan adalah metode kualitatif dengan analisis deskriptif pada studi atau hasil kajian yang relevan dan hasil pemantauan ujian nasional. Hasil kajian menunjukkan bahwa ujian berbasis komputer dapat dilaksanakan di seluruh wilayah atau satuan pendidikan bila didukung oleh perangkat komputer dan internet. Agar pelaksanaan ujian berbasis komputer dapat berjalan dengan lancar, satuan pendidikan harus menyiapkan perangkat keras, jaringan internet, dan jaringan lokal komputer. Selain itu, hasil kajian model ujian nasional berbasis komputer adalah menghemat biaya penggandaan naskah, keamanan naskah, memudahkan distribusi bahan, mudah menjangkau seluruh wilayah, keamanan, mudah proses penskoran, dan memungkinkan pencetakan sertifikat hasil ujian dilakukan setelah ujian berlangsung. Hambatan model ujian nasional berbasis komputer antara lain cakupan wilayah yang luas, perangkat keras, sarana internet, dan dukungan para pemangku kepentingan. Namun demikian, pelaksanaan ujian nasional dapat dilaksanakan di seluruh wilayah seiring dengan kemajuan teknologi informasi. Kajian ini menyimpulkan bahwa penerapan ujian nasional berbasis komputer secara langsung dalam wilayah terbatas baik
\end{abstract}


kabupaten/kota, provinsi, maupun nasional akan memotong rangkaian penyelenggaraan ujian nasional sehingga membantu pemangku kepentingan dan hasil ujian nasional berupa nilai dan sertifikat ujian nasional akan segera diperoleh atau dimiliki peserta didik setelah pelaksanaan ujian berlangsung, tidak seperti selama ini, dimana peserta didik harus menunggu lama untuk memperoleh hasil tersebut.

Kata kunci: ujian nasional berbasis komputer, ujian nasional langsung, ujian tertulis, model ujian, teknologi informasi

\section{PENDAHULUAN}

Penggunaan teknologi dalam pembelajaran telah lama dimanfaatkan untuk membantu peningkatan kualitas pembelajaran. Pemanfaatan teknologi dalam proses pembelajaran terutama teknologi komputer memudahkan para pendidik untuk menjelaskan materi pembelajaran yang bersifat abstrak dan jauh dari penalaran peserta didik menjadi mudah dijangkau atau dipahami. Melalui teknologi pembelajaran para pendidik akan mudah melakukan simulasi pembelajaran mendekati kondisi nyata dari suatu materi pembelajaran yang abstrak, misalnya penjelasan tentang gerakan lempeng tektonik yang menimbulkan banyak korban mudah diuraikan dengan bantuan simulasi teknologi. Simulasi gerakan lempeng tektonik melalui animasi akan memudahkan pemahaman dan penghayatan peserta didik untuk materi pembelajaran tersebut.

Penggunaan teknologi pembelajaran semakin kuat pengaruhnya seiring dengan perkembangan teknologi informasi dan komunikasi (TIK) yang telah merambah kehidupan masyarakat. Pembelajaran menggunakan TIK sering disebut dengan e-learning yang merupakan proses pembelajaran melalui penggunaan teknologi atau internet pada khususnya atau pembelajaran berbasis komputer (Nurchaili, 2010). Penggunaan internet dalam proses pembelajaran menjadikan proses pembelajaran berbeda dengan pembelajaran yang dilakukan pendidik sebelum mengenal TIK sehingga akan menarik perhatian peserta didik dalam proses pembelajaran. Pemanfaatan TIK dalam pembelajaran telah mengubah proses pembelajaran "dari ruang kelas ke mana saja, dari waktu siklus ke waktu nyata, dari kertas ke online, dan dari fasilitas fisik ke jaringan kerja" (Abdullah, 2009). Pembelajaran dapat berlangsung di ruang sekolah atau di rumah atau dimana saja bergantung pada kemauan peserta didik. Pemanfaatan TIK ini menyebabkan proses pembelajaran dapat terlaksana tanpa ada pembatasan waktu sepanjang peserta didik mau melakukannya. Hal itu akan mendorong peserta didik untuk meningkatkan kompetensinya sesuai dengan kemampuan dan keinginan belajarnya.

Pemanfaatan TIK dalam proses pembelajaran dilakukan dalam berbagai bentuk antara lain penyediaan bahan ajar secara online (bahan ajar tersimpan dalam bentuk buku atau artikel di internet), program computer assisted learning, bahan alat peraga atau simulasi, pembelajaran Moodle dan Facebook (Darmawan dan Siti, 2014), dan pembelajaran jarak jauh (sekolah terbuka). Penyediaan bahan ajar secara online memudahkan pendidik atau peserta didik untuk menemukan bahan ajar sehingga proses pembelajaran tidak terkendala oleh materi bahan ajar yang tidak tersedia. Ketersediaan bahan ajar secara tepat waktu akan memperlancar dan membantu pendidik atau peserta didik untuk memahami materi pembelajaran secara komprehensif sehingga pembelajaran terhindar kesalahan konsepsi (misconcept). Pembelajaran dengan penggunaan alat peraga atau simulasi melalui TIK akan memudahkan materi pelajaran dipahami oleh peserta didik serta akan berdampak pada minat atau perhatian peserta didik pada pelajaran tersebut. Adanya alat peraga dengan penerapan TIK akan membuat pembelajaran lebih menyenangkan dan menarik perhatian 
peserta didik. Dengan demikian, komputer berfungsi untuk membantu peserta didik untuk memelajari materi pelajaran secara terprogram sesuai dengan kompetensi yang ditetapkan dalam kurikulum serta perkembangan kemampuannya.

Penerapan TIK dalam pembelajaran Moodle dan Facebook lebih mengandalkan pembelajaran dengan penggunaan internet secara langsung (Darmawan dan Siti, 2014). Penerapan TIK untuk pendidikan jarak jauh telah berkembang lama terutama di negara maju. Dalam penggunaan TIK jarak jauh dilakukan secara interaktif antara pendidik dengan peserta didik. Hasil pengamatan penulis tahun 1995 di Australia Selatan menunjukkan pendidik (guru) berada di pusat belajar atau satuan pendidikan sedangkan peserta didiknya ada di pedalaman Australia (Outback) dan terpencar satu sama lain. Pendidik menjelaskan materi pelajaran melalui internet kepada peserta didik di pedalaman dan bila ada yang kurang jelas, peserta didik dapat meminta penjelasan ulang secara online. Melalui penggunaan TIK yang ada, peserta didik dapat mengajukan pertanyaan kepada pendidik dan dijawab secara langsung. Pada akhir pembelajaran pendidik memberikan tugas sebagai penilaian pembelajaran dan setelah tugas dikerjakan maka dilakukan diskusi secara langsung (online). Hasil penilaian digunakan sebagai umpan balik secara langsung melalui interaksi dua arah sehingga pemahaman peserta didik pada materi yang didiskusikan dipahami peserta didik secara benar. Peserta didik yang berhasil dalam program pendidikan jarak jauh tersebut diberikan sertifikat (ijazah) dengan penghargaan yang sama dengan ijazah dari satuan pendidikan yang setara SD, SMP, atau SMA sesuai dengan program yang diikuti oleh peserta didik.

Pemanfaatan TIK dalam pembelajaran diyakini dapat meningkatkan kualitas pembelajaran dan peserta didik lebih mudah untuk menerima materi pembelajaran. Untuk mengukur pencapaian peserta didik dalam proses pembelajaran dilakukan penilaian. Penilaian dalam proses pembelajaran, menurut Bennet dan Gitomer (2009) dibedakan sebagai alat untuk mendeteksi kesulitan belajar (assessment as learning), penilaian proses pembelajaran (assessment for learning), dan penilaian untuk mengukur pencapaian hasil belajar (assessment of learning). Penilaian dilaksanakan sebagai upaya melayani dan mendeteksi kesulitan belajar yang dialami peserta didik. Dari hasil penilaian setelah proses pembelajaran dilakukan diketahui materi (kompetensi) yang belum dipahami atau dikuasai oleh peserta didik. Berdasarkan kesulitan atau materi yang belum dipahami peserta didik, pendidik dapat melakukan remedial atau penugasan sehingga peserta didik mencapai kompetensi atau materi yang ditentukan. Penilaian tersebut dikenal dengan penilaian dalam kelas yaitu penilaian yang berlangsung selama dan pada akhir pembelajaran. Penilaian tersebut berfungsi untuk meningkatkan mutu proses pembelajaran (Muslich, 2011). Penilaian tersebut lebih mengukur pencapaian peserta didik selama proses pembelajaran di tingkat kelas dan pada akhir pembelajaran peserta didik dalam satuan atau jenjang pendidikan dilakukan ujian akhir.

Ujian akhir merupakan penilaian pencapaian kompetensi peserta didik selama mengikuti proses pembelajaran di satuan pendidikan. Tujuan ujian akhir adalah untuk memeroleh gambaran pencapaian kompetensi peserta didik selama mengikuti pendidikan yang meliputi aspek pengetahuan, keterampilan, dan sikap (Basuki dan Hariyanto, 2014). Ujian akhir yang dilakukan Pemerintah dalam sistem pendidikan nasional, saat ini disebut Ujian Nasional, adalah sebagai upaya penilaian pencapaian kompetensi nasional pada kelompok ilmu pengetahuan dan teknologi, yaitu mata pelajaran yang ditetapkan oleh Kementerian Pendidikan dan Kebudayaan (Kemdikbud). Ujian Nasional ini diselenggarakan oleh pemerintah yang meliputi aspek pengetahuan (akademis), sedang aspek keterampilan dan sikap diserahkan kepada satuan pendidikan yang berkaitan. Ujian nasional untuk mengukur aspek pengetahuan dilaksanakan dalam bentuk 
tertulis (paper and pencil test-PBT) dan berbasis komputer (computer based test-CBT) dengan bentuk soal pilihan ganda sedang bentuk penilaian untuk aspek keterampilan dan sikap yaitu penilaian praktik, produk, proyek, dan observasi yang dilakukan oleh satuan pendidikan. Ujian Nasional dengan model PBT merupakan pelaksanaan ujian secara tertulis seperti yang dilakukan selama ini, sedang model $C B T$ yang disebut Ujian Nasional Berbasis Komputer (UNBK) merupakan pelaksanaan ujian berbasis komputer dengan soal yang setara dengan ujian model PBT. Penggunaan komputer dalam ujian memudahkan pelaksana untuk membuat soal beragam dengan mengombinasikan beberapa paket soal (Abdullah, 2009) sebab dalam ujian nasional menggunakan soal yang berbeda antar peserta didik dengan tingkat kesukaran relatif setara. Penyelenggaraan ujian nasional yang pesertanya banyak dan hasilnya harus segera diketahui, maka penggunaan TIK dalam pelaksanaan ujian nasional dapat membantu penyelenggara Ujian Nasional. Pengolahan hasil Ujian Nasional yang dilaksanakan sampai saat ini baik PBT maupun CBT relatif lama, karena hasil ujian harus dipindai (scan) di provinsi dan kemudian hasilnya dikirimkan ke Kemdikbud (Panitia Tingkat Pusat) untuk dilakukan penskoran dan hasilnya dikirimkan kembali ke provinsi hingga satuan pendidikan.

Berdasarkan uraian tersebut, maka permasalahan dalam kajian ini adalah: 1) bagaimanakah pelaksanaan UNBK?; 2) bagaimanakah model UNBK?; dan 3) apakah hambatan penerapan model ujian tersebut? Kajian model UNBK urgen dilakukan agar hasil Ujian Nasional segera diperoleh peserta didik dan bila hasilnya kurang peserta didik dapat dengan segera memperbaikinya sesuai waktu yang ditentukan. Hal itu perlu dilakukan karena peserta didik perlu waktu untuk mempersiapkan dirinya untuk melanjutkan pendidikan atau mencari pekerjaan. Atas permasalahan tersebut, tujuan kajian dimaksudkan untuk: 1) memeroleh gambaran pelaksanaan UNBK; 2) memberikan informasi tambahan dalam penyempurnaan UNBK yang berlangsung sekarang ini hingga dalam pelaksanaan ujian segera diketahui hasilnya setelah ujian berlangsung; dan 3) mengkaji hambatan penerapan model UNBK.

\section{KAJIAN LITERATUR E-learning}

Penggunaan TIK dalam kehidupan sehari-hari sudah merupakan kebutuhan untuk mempermudah interaksi antarmasyarakat. Di lingkungan sekitar kita, tampak produk-produk TIK yang memengaruhi kehidupan seperti televisi, telepon genggam, pemutar DVD/VCD, Ipods, laptop atau komputer. Produk tersebut sangat membantu dalam pemenuhan kebutuhan kita dalam rangka mempertahankan kehidupan. Adanya produk TIK tersebut memudahkan dalam berkomunikasi dan berinteraksi. Melalui siaran dan acara televisi kita dapat mengetahui perkembangan berita yang ada di dunia serta sebagai sarana hiburan. Telepon genggam memudahkan kita berkomunikasi tanpa ada batas atau sekat-sekat. Demikian pemutar DVD/ $V C D$ dapat digunakan sebagai sarana hiburan di rumah atau kegiatan olahraga (senam) sedang komputer digunakan untuk berbagai keperluan seperti sebagai sarana belajar, mencari informasi, atau sarana hiburan.

Pengaruh perkembangan TIK yang demikian pesat merambah seluruh lapisan kehidupan termasuk di dalamnya dunia pendidikan. Perkembangan teknologi dalam dunia pendidikan memberikan peluang perubahan dan kemungkinan baru di dunia pendidikan. Berbagai produk TIK menyebabkan perubahan dalam proses interaksi pembelajaran di satuan pendidikan. Produk TIK telah memaksa para pendidik untuk mengubah strategi dalam proses pembelajaran dengan penerapan produk-produk TIK. Pemanfaatan TIK dalam proses pembelajaran menjadikan pembelajaran yang inovatif, lebih interaktif, dan kolaboratif, sehingga tujuan pembelajaran tercapai secara efektif dan menyenangkan (Purwanto, 2004). Proses pembelajaran dengan memanfaatkan produk TIK 
dikenal dengan pembelajaran e-learning yang dilaksanakan dalam berbagai bentuk seperti penyediaan bahan ajar secara online, pembelajaran jarak jauh, pembelajaran Moodle dan Facebook, program computer assisted learning atau pembelajaran berbasis komputer.

Pembelajaran e-learning merupakan pembelajaran online dengan menggunakan format digital melalui teknologi informasi (Kusnohadi, 2014). Pembelajaran yang dilakukan pendidik pada dasarnya merupakan pembe-lajaran konvensional di dalam kelas atau di luar kelas dengan menerapkan berbagai produk TIK sebagai media pembelajaran dalam bentuk multi media, yaitu perpaduan antara teks, grafis, suara, animasi, dan video yang disajikan dalam komputer atau media elektronik (Tanrere dan Sumiati, 2012). Pembelajaran dengan menggunakan TIK dipercaya memberikan hasil pembelajaran yang lebih unggul dibandingkan tanpa menggunakannya. Mengapa demikian, karena dengan bantuan produk TIK para peserta didik dapat lebih mudah untuk menguasai materi pelajaran dan bahkan peserta didik dapat ditugaskan memelajari materi atau kompetensi yang lebih dengan mencari materi yang relevan melalui internet atau multimedia. Bentuk multimedia yang diperlukan untuk menunjang kegiatan pembelajaran di satuan pendidikan yaitu multimedia interaktif (Waldopo, 2011), dimana peserta didik dapat belajar secara aktif dengan menggunakan media elektronik seperti video, VCD, DVD. Media elektronik tersebut memuat materi pembelajaran dan peserta didik dapat mengamati proses yang terjadi dan kegiatan yang berkaitan dengan topik bahasan tertentu dari materi pembelajaran. Media tersebut dapat dilakukan secara berulang sehingga peserta didik memahami materi tersebut.

Pembelajaran dengan memanfaatkan TIK dapat memberi kebebasan peserta didik untuk memelajari materi atau kompetensi sesuai dengan kemampuan dan minatnya. Dalam hal ini pendidik berfungsi sebagai fasilitator atau pembimbing untuk mengarahkan materi atau pengetahuan yang diperoleh peserta didik melalui pembelajaran online dalam proses pembelajaran di kelas. Kebebasan yang dimiliki peserta didik untuk belajar atau mendalami suatu materi atau kompetensi berdampak pada kemampuan belajar dan wawasan serta peserta didik merasakan belajar itu menyenangkan. Pembelajaran dengan penerapan TIK dapat meningkatkan hasil proses pembelajaran dan menguatkan hasil pembelajaran di kelas (Evranita, 2009) serta menambah wawasan dan keterampilan peserta didik. Untuk mengetahui hasil proses pembelajaran maka dilakukan penilaian yang berfungsi memberikan informasi tentang peserta didik yang sudah atau belum memahami materi pembelajaran. Hasil penilaian digunakan sebagai bahan diskusi dengan peserta didik ataupun orang tua (wali) untuk meningkatkan penguasaan materi atau kompetensi peserta didik. Proses ini akan meningkatkan hasil pembelajaran sebab bagi peserta didik yang belum memahami pelajaran dapat memelajarinya lebih lanjut di rumah dengan bimbingan orang tua (wali).

Penilaian merupakan bagian dari proses pembelajaran yang bertujuan untuk mengetahui sejauhmana proses pembelajaran yang dilakukan berhasil atau tidak. Melalui penilaian yang dilakukan pendidik dapat mendeteksi materi yang sudah dikuasai dan belum oleh peserta didik. Materi yang belum dikuasai dapat dijadikan sebagai bahan pembelajaran ulang atau menjadi materi penugasan sehingga peserta didik dapat menguasainya. Penilaian dalam proses pembelajaran terdiri atas penilaian formatif dan sumatif (Nitko dan Susan, 2011). Penilaian formatif dapat membantu para pendidik untuk memantau perkembangan kemampuan peserta didik dan hasil penilaian digunakan untuk meningkatkan kemampuan peserta didik dan mendeteksi kesulitan belajar peserta didik. Penilaian formatif dilakukan dalam bentuk ulangan harian atau penugasan selama proses pembelajaran. Penilaian sumatif dilakukan untuk mengetahui capaian peserta didik setelah proses pembelajaran berlangsung satu semester atau atau satu tahun pembelajaran dalam bentuk 
ulangan semester, kenaikan kelas, atau ujian akhir. Penilaian dilakukan dalam rangka pencapaian kompetensi selama peserta didik mengikuti pendidikan di suatu satuan pendidikan tertentu. Pengukuran kompetensi mutlak dilakukan sebagai bahan pertanggungjawaban satuan pendidikan kepada masyarakat atau pemerintah atau suatu yayasan tentang kemajuan belajar peserta didik yang yang telah dipercayakan pada satuan pendidikan.

\section{Ujian Berbasis Komputer}

Dalam sistem pendidikan nasional, ujian akhir sudah ada sejak masa kemerdekaan (bahkan di masa penjajahan) hingga kini dengan sebutan yang berbeda-beda. Dewasa ini, ujian akhir oleh pemerintah disebut Ujian Nasional sebagai bagian dari evaluasi sebagaimana diamanatkan Undang-Undang Nomor 20 Tahun 2003. Ujian nasional adalah kegiatan pengukuran dan penilaian pencapaian standar kompetensi lulusan pada jenjang SMP dan SMA yang sederajat pada mata pelajaran tertentu, (BSNP, 2015), sedangkan Silverius (2010) menyatakan ujian nasional merupakan jenis penilaian yang dilakukan pemerintah untuk mengukur keberhasilan peserta didik yang telah menyelesaikan jenjang pendidikan pada jalur sekolah/madrasah yang diselenggarakan secara nasional. Oleh karena itu, Ujian Nasional diselenggarakan pada akhir pembelajaran di satuan pendidikan untuk menentukan pencapaian pembelajaran peserta didik di SMP dan SMA sederajat. Penilaian hasil belajar yang dilakukan pemerintah merupakan upaya penguatan hasil penilaian internal oleh pendidik maupun satuan pendidikan (Hadiana, 2015). Dengan demikian, penilaian yang dilakukan pemerintah atau disebut penilaian eksternal, merupakan bentuk penilaian yang saling melengkapi dan menguatkan hasil pendidikan di satuan pendidikan.

Penilaian dengan memanfaatkan komputer, pada awalnya berkembang di pusat-pusat konseling di bidang psikologi (Gregory, 2013) untuk membantu para klien yang mengalami hambatan di bidang psikologi. Komputer digunakan untuk menerima pendaftaran klien yang dapat mengikuti penilaian dan secara otomatis klien dapat dihadapkan pada sejumlah butir soal pada komputer serta secara otomatis dapat keluar hasil aspek yang di nilai dari seorang klien setelah pelaksanaan penilaian. Pemanfaatan komputer untuk penilaian di kalangan psikologi semakin berkembang dan termasuk pemanfaatannya di bidang pendidikan khususnya untuk penilaian hasil belajar. Dalam pelaksanaan penilaian (ujian) memunculkan dua alur yaitu ujian tertulis atau $P B T$ dan ujian berbasis komputer atau CBT. PBT merupakan pelaksanaan ujian berbasis kertas seperti dilakukan selama ini, sedang $C B T$ merupakan pelaksanaan ujian berbasis komputer. Model CBT menurut Luecht dan Sireci (2011) dikelompokkan menjadi: 1) Computerized Fixed Tests (CFT); 2) Linear-on-the-Fly, Tests (LOFT); 3) Computerized Adaptive Tests (CAT); 4) aStratified Computerized Adaptive Testing (AS); 5) Content-Constrained CAT with Shadow Tests; 6) Testlet-Based CAT and Multistage Computerized Mastery Tests (combined); dan 7) Computer-Adaptive Multistage Testing. Setiap model memiliki kelebihan dan kekurangan dalam pelaksanaan ujian serta model-model tersebut dapat dibedakan menjadi ujian berbasis komputer dengan paket soal pasti/tertentu (CBT) dan soal yang diatur atau disesuaikan dengan kemampuan peserta ujian (CAT). Model CAT memuat sejumlah butir soal dengan tingkat kesukaran yang bervariasi dan karakteristik butir soal lainnya. Peserta ujian langsung menghadap komputer dan butir soal yang dapat dikerjakan muncul satu per satu di layar komputer sesuai dengan kemampuan peserta ujian. Dari soal yang tersedia bila peserta ujian tidak dapat menjawab atau salah menjawab pada tingkat tertentu maka ujian berakhir. Berdasarkan soal yang dapat dikerjakan dapat diketahui atau diperoleh tingkat kemampuan peserta ujian dan bila melampui target yang telah ditetapkan maka peserta ujian dinyatakan berhasil dan bila belum peserta ujian dapat mengulang kembali sampai yang bersangkutan dinyatakan lulus. 
Ujian Nasional Tahun 2015 yang menerapkan ujian berbasis komputer yang disebut UNBK, merupakan ujian yang relatif setara dengan ujian tertulis seperti selama ini dilakukan. Perbedaannya terletak pada soal yang tersedia dalam file komputer. Kajian pelaksanaan ujian berbasis komputer dilakukan oleh Santosa (2009) yang meneliti pengukuran hasil belajar mahasiswa universitas terbuka. Hasil kajiannya menunjukkan bahwa pengukuran hasil belajar mahasiswa dapat dilakukan melalui ujian yang berbasis komputer. Pengembangan perangkat lunak atau aplikasi untuk menunjang pelaksanaan ujian nasional telah dikembangkan oleh Puspendik meliputi infrastruktur (jaringan komputer), aplikasi program, pengembangan bank soal terkalibrasi, dan sumber daya manusia (Bagus, 2013). Keberhasilan pelaksanaan UNBK sangat ditentukan ketersediaan aplikasi program dan jaringan internet. Melalui pengembangan perangkat tersebut, pelaksanaan UNBK dapat dilakukan secara online sebagaimana kajian dari Suprananto (2012) secara khusus untuk ujian Pendidikan Kesetaraan. Model UNBK masa depan dimaksudkan pelaksanaan ujian dilakukan secara online baik dalam lingkup kabupaten/kota atau provinsi atau nasional dan hasil ujian segera diperoleh peserta didik setelah mengikuti ujian. Model UNBK ini juga diharapkan dapat melayani peserta didik yang telah menggunakan Kurikulum 2013 dengan sistem kredit semester. Dengan demikian, peranan teknologi dapat mempercepat hasil ujian hingga sertifikat dapat diperoleh peserta didik setelah pelaksanaan ujian berlangsung. Hal itu, dapat berdampak pada adanya peluang atau waktu untuk mempersiapkan diri peserta didik yang ingin melanjutkan pelajaran ke jenjang yang lebih tinggi ataupun untuk meningkatkan kompetensi bagi sekolah kejuruan.

\section{METODE}

Metode penelitian yang digunakan metode kualitatif yang memiliki ciri khusus antara lain penekanan pada pengalaman langsung, proses, dan penafsiran peneliti (Raco, 2010). Penelitian dilakukan dengan diamati secara langsung untuk mendapatkan informasi pelaksanaan UNBK dan informasi tersebut dianalisis secara deskriptif dengan menggabungkan sejumlah dokumen pelaksanaan Ujian Nasional yaitu Peraturan Menteri Nomor 5 Tahun 2015 Kriteria Kelulusan Peserta Didik, Penyelenggaraan Ujian Nasional, dan Penyelenggaraan Ujian Sekolah/Madrasah/ Pendidikan Kesetaraan Pada SMP/MTs Atau Yang Sederajat Dan SMA/MA/SMK Atau Yang Sederajat dan Peraturan Badan Standar Nasional Pendidikan Nomor 0031/P/BNSP/III/2015 tentang Prosedur Operasi Standar Penyelenggaraan Ujian Nasional Tahun Pelajaran 2014/ 2015 serta sejumlah tulisan tentang ujian berbasis komputer. Analisis deskriptif dilakukan dalam arti penelaahan pada dokumen peraturan Ujian Nasional kemudian dirangkai dengan hasil pengamatan penulis dalam pelaksanaan Ujian Nasional. Informasi tersebut dirangkai dengan hasil kajian dari berbagai pustaka atau tulisan para pakar serta ditafsirkan atau diinterpretasikan secara umum menjadi tulisan ini.

\section{HASIL DAN PEMBAHASAN}

\section{Ujian Nasional Berbasis Komputer (UNBK)}

Pelaksanaan UNBK dalam sistem pendidikan nasional mulai dirintis penerapannya pada tahun 2013 di sekolah Indonesia di Singapura dan Malaysia. Sekolah tersebut dipilih karena kesiapan sekolah dan ketersediaan fasilitas komputer untuk digunakan peserta didik dalam ujian. Sekolah tersebut merupakan sekolah rintisan dalam penerapan UNBK dan sekaligus merupakan jawaban atas permintaan pimpinan kementerian yang menginginkan penyempurnaan dalam pelaksanaan ujian nasional yang selama ini dilakukan dalam bentuk tertulis (PBT).

Upaya pemanfaatan komputer dalam penyelenggaraan ujian nasional telah dikembangkan sejak lama oleh Pusat Penilaian Pendidikan (Puspendik, 2008). Pada awalnya, model atau aplikasi yang dikembangkan adalah CAT yaitu model ujian dengan interaksi langsung dengan komputer yang telah tersedia sejumlah butir soal dan peserta ujian, diuji sesuai dengan 
kemampuannya. Ujian berhenti bila peserta ujian menjawab soal salah pada sejumlah butir soal dengan tingkat kesukaran tertentu sesuai dengan kemampuan peserta ujian. Berdasarkan data tingkat kesukaran soal yang dijawab salah dan benar, komputer secara otomatis menghitung (estimasi) kemampuan optimum peserta ujian. Hasil CAT ditentukan pada estimasi kemampuan peserta ujian berdasarkan soal yang dikerjakan. Model CAT memberikan soal sesuai dengan kemampuan peserta ujian. Bila kemampuan peserta ujian rendah maka akan muncul soal dengan tingkat kesukaran rendah. Sedang bila kemampuan peserta ujian tinggi maka muncul soal dengan tingkat kesukaran tinggi. Dalam CAT dapat diestimasi tingkat kemampuan setiap peserta ujian. Peserta didik dinyatakan selesai menempuh ujian bukan didasarkan pada banyaknya butir soal yang dikerjakan dengan benar. Namun, menurut estimasi optimum peserta didik yang dilakukan secara otomatis oleh komputer.

Dalam pengembangan model CAT ada dua komponen besar yang dikembangkan yaitu perangkat lunak dan butir soal serta penyediaan perangkat keras tentunya. Dalam pengembangan perangkat lunak dibuat program aplikasi untuk menghitung estimasi kemampuan peserta ujian dan program yang dapat mengeluarkan soal sesuai kemampuan peserta ujian. Pengembangan butir soal dilakukan dengan mengikuti pengembangan soal teori responsi butir. Dalam teori tersebut dinyatakan ada dua hal yang berpengaruh terhadap hasil ujian yaitu tingkat kesukaran soal (measure) dan tingkat kemampuan peserta ujian (ability). Pengembangan dua komponen utama dilakukan selama bertahun-tahun, sedang untuk pengembangan perangkat keras diserahkan pada satuan pendidikan dan dinas pendidikan atau yayasan pendidikan untuk sekolah swasta.

Pada awalnya, aplikasi CAT telah dikembangkan beberapa tahun yang lalu oleh Puspendik serta telah diujicobakan di Puspendik (2008) kepada peserta didik kelas XI dan XII SMA dan SMK di Jabodetabek. Selanjutnya, model ini diujicobakan pada beberapa satuan pendidikan dan secara online di beberapa provinsi. Kelebihan CAT menurut Weiss dan Vale dalam Gregory (2013) adalah presisi dan efisiensi. Dalam CAT, peserta ujian diukur dengan derajat yang setara karena ujian terus berlanjut sampai kriteria terpenuhi atau kemampuan optimum. Efisiensi dalam CAT terjadi karena CAT tidak membutuhkan butir soal yang banyak karena dalam ujian komputer secara otomatis dapat mengeluarkan soal sesuai dengan tingkat kemampuan peserta ujian. Berbeda dengan ujian tradisional atau PBT yang dikembangkan dengan teori klasik membutuhkan lebih banyak butir soal karena untuk mengukur kemampuan optimum peserta ujian dapat dilakukan secara berulangulang hingga perlu soal banyak (Gregory, 2013). Lebih lanjut Gregory membandingkan jumlah butir soal untuk ujian sertifikasi tertulis membutuhkan butir soal 200-500 soal sedang melalui CAT hanya diperlukan sekitar 100 soal. Oleh karena itu, pendekatan CAT banyak digunakan oleh organisasi besar di dunia seperti Angkatan Darat dan Educational Testing Service di Amerika Serikat, serta organisasi profesi seperti bidang psikologi dan kedokteran.

Pendekatan CAT dalam ujian akhir sangat menguntungkan dan efisien namun dalam proses pengembangan butir soal sangat rumit karena butir harus dikembangkan menurut teori responsi butir (item response theory), soal sudah terkalibrasi, dan tersedia soal dengan tingkat kesukaran sesuai atau mendekati kemampuan peserta ujian (Bagus, 2012), sementara sebagian besar satuan pendidikan masih menggunakan ujian nasional secara tertulis. Oleh karena itu, CAT dalam ujian nasional belum diterapkan namun tetap dengan menggunakan komputer atau pendekatan $C B T$ yang disebut UNBK. Dalam UNBK, peserta ujian berinteraksi secara langsung dengan komputer yang memuat butir soal dari mata pelajaran diujikan. Peserta ujian menjawab butir soal seperti ujian tertulis (PBT) dalam komputer. Jumlah butir soal ditentukan sebagaimana ujian tertulis dan karakteristik butir tidak berfungsi 


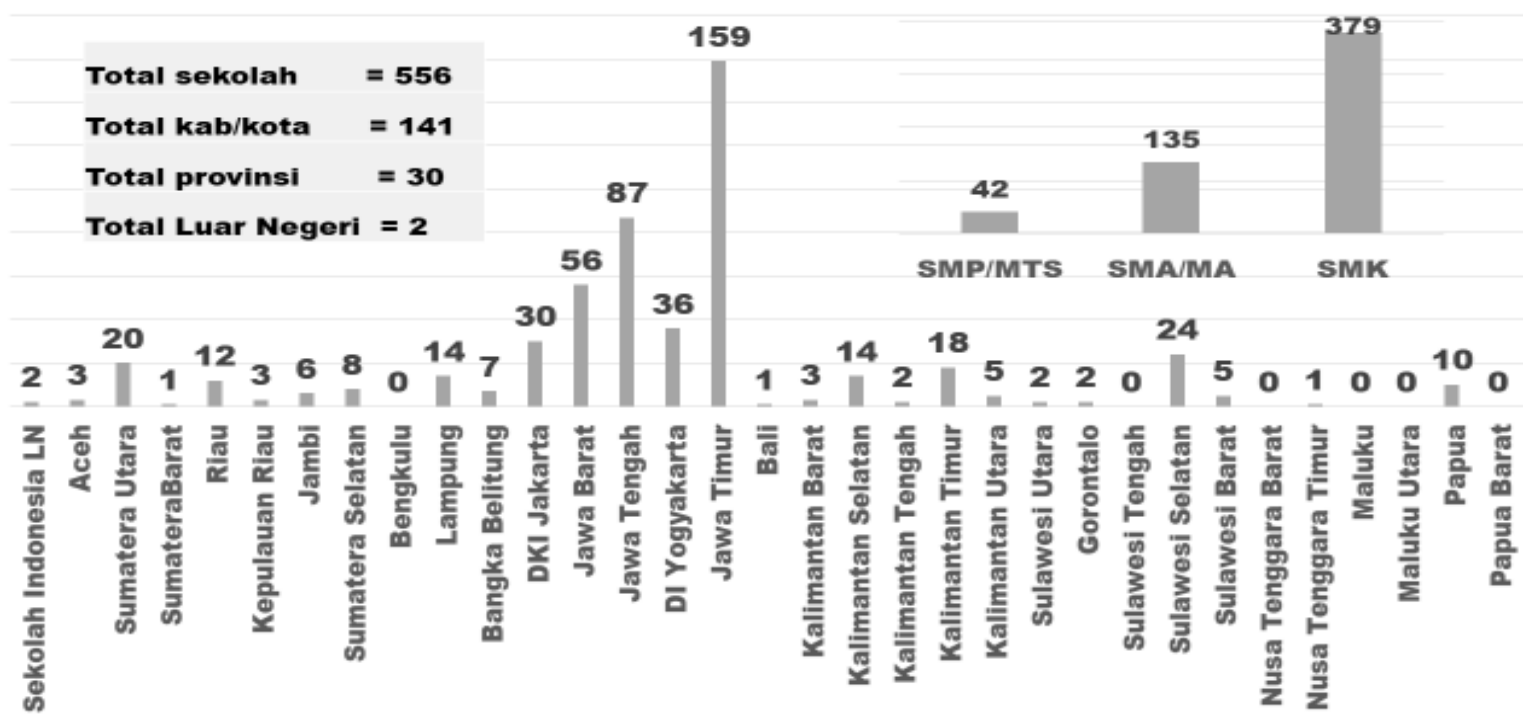

Grafik 1 Sekolah Yang Melaksanakan UNBK Tahun 2015

Sumber Data: Pusat Penilaian Pendidikan, 2015

sebagaimana dengan pendekatan CAT. UNBK dilaksanakan dengan menggunakan satu komputer untuk satu peserta ujian. Materi atau soal ujian sudah dimasukkan ke dalam komputer dan peserta ujian menjawab pertanyaan serta memberi jawaban dalam komputer tersebut.

Pemanfaatan UNBK dalam sistem pendidikan nasional diterapkan pada beberapa satuan pendidikan yang memenuhi persyaratan dan di mulai pada ujian nasional tahun 2015 seperti tampak dalam Grafik 1.

Berdasarkan Grafik 1 tampak bahwa Ujian Nasional berbasis komputer dapat dilaksanakan secara serentak pada satuan pendidikan yang telah ditetapkan. Jumlah satuan pendidikan yang melaksanakan UNBK yaitu SMP sebanyak 42 sekolah, SMA sebanyak 135 sekolah, dan SMK 379 sekolah serta yang menerapkan UNBK paling banyak di provinsi Jawa Timur (159 sekolah). Provinsi yang belum melaksanakan UNBK adalah provinsi Papua Barat, Maluku Utara, Maluku, Sulawesi Tengah, dan Bengkulu. Jumlah yang menerapkan UNBK diharapkan dapat bertambah pada pelaksanaan ujian nasional pada tahun-tahun mendatang seiring dengan upaya sosialisasi pelaksanaan UNBK kepada pemangku kepentingan. Hasil pemantauan menunjukkan bahwa pemangku kepentingan belum mengikutsertakan satuan pendidikan dalam pelaksanaan UNBK disebabkan kekurangpahaman pelaksanaan UNBK, khawatir kelangsungan listrik pada saat ujian terutama di daerah yang sering mengalami pemadaman listrik, serta kekurangan sarana komputer di satuan pendidikan. Dengan demikian ujian nasional telah dapat dilaksanakan secara offline atau berbasis komputer di 556 sekolah, 141 kabupaten/kota, dan 30 provinsi.

Untuk mendukung pelaksanaan UNBK ada dua komponen utama yang perlu disiapkan yaitu penyiapan perangkat keras dan perangkat lunak. Ketersediaan komponen tersebut dapat mendukung proses pelaksanaan ujian nasional berbasis komputer. Penyiapan perangkat keras meliputi komputer, internet, dan jaringan lokal komputer. Proses penyiapan perangkat keras dilakukan oleh satuan pendidikan dan dinas pendidikan kabupaten/kota atau provinsi. Penyiapan perangkat keras ini hendaknya dikaitkan dengan penyediaan sarana pembelajaran bukan hanya untuk pelaksanaan ujian nasional sehingga biaya yang dikeluarkan tidak terasa berat karena komputer tersebut digunakan untuk pembelajaran dan pelaksanaan 
ujian. Komputer yang diperlukan untuk pelaksanaan UNBK adalah satu komputer untuk satu orang peserta ujian. Dalam praktiknya, satu komputer bisa digunakan oleh tiga peserta ujian secara bergantian dalam satu hari ujian sesuai jadwal yang telah ditentukan. Kemudian yang perlu disiapkan adalah jaringan internet dengan jaringan lokal untuk tingkat satuan pendidikan.

Penyiapan perangkat lunak (aplikasi) dilakukan oleh Puspendik meliputi perangkat lunak komputer dan perangkat soal. Perangkat lunak dikembangkan agar dalam proses pelaksanaan UNBK, komputer dapat mengeluarkan soal secara teratur selama ujian berlangsung untuk setiap peserta ujian. Perangkat soal memuat sehimpunan butir soal (paket soal) yang telah memiliki karakteristik butir soal. Ujian dapat berakhir setelah waktu yang disediakan berakhir atau peserta ujian telah menyelesaikan seluruh soal yang diperuntukkan pada peserta ujian. Dalam pelaksanaan ujian, perangkat lunak tersebut dihubungkan dengan jaringan lokal di satuan pendidikan dengan komputer yang digunakan dalam pelaksanaan ujian nasional. Jaringan lokal ini menghubungkan satu komputer dengan komputer lainnya sehingga dalam pelaksanaan ujian nasional terdapat pusat atau server untuk

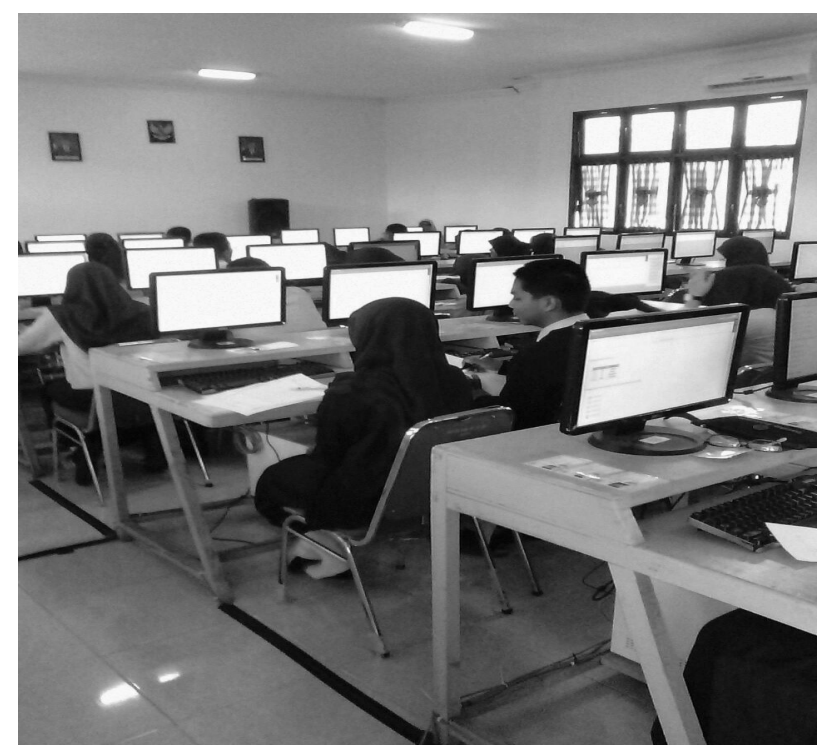

setiap satuan pendidikan. UNBK dilaksanakan secara klasikal dengan alokasi waktu yang ditentukan untuk setiap mata pelajaran. Dalam satu hari ujian ditentukan dengan tiga sesi sehingga satu komputer dalam ujian dapat digunakan oleh tiga peserta didik. Pelaksanaan UNBK dilakukan secara klasikal pada satuan pendidikan yang telah dipersiapkan seperti tampak dalam Gambar 1.

UNBK berlangsung setelah peserta ujian masuk ke ruang ujian dan menghadap komputer yang telah disediakan. Peserta ujian dapat mengisikan informasi data setiap peserta didik dalam komputer yang digunakan. Peserta ujian mengisi identitas pengguna (user id) dan sandi pembuka (password). Bila identitas pengguna dan sandi pembuka sesuai maka akan muncul halaman informasi tentang identitas pengguna (peserta ujian), mata pelajaran, waktu mengerjakan, dan petunjuk umum. Informasi tersebut diperlukan peserta didik (ujian) agar mereka tidak kehilangan kesempatan mengerjakan soal dan hasil yang mereka kerjakan sesuai dengan identitas mereka. Proses berikutnya adalah untuk mengaktifkan token semacam sandi pembuka dan muncul materi soal serta waktu untuk mengerjakan soal. Bila ada kendala yang dihadapi peserta ujian dalam

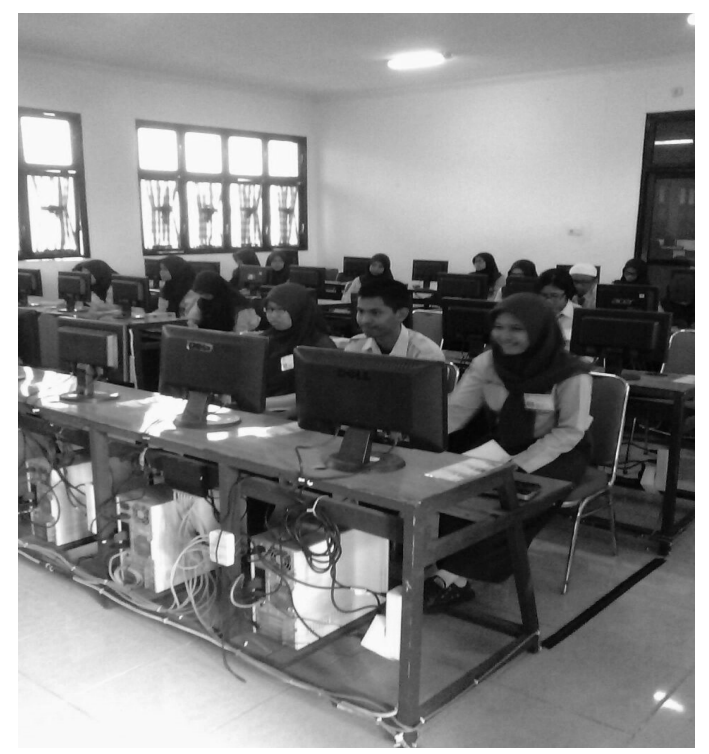

Gambar 1 Pelaksanaan UNBK (Sumber: Koleksi penulis) 
kelancaran atau pengaktifan komputer, peserta dapat dibantu oleh petugas yang telah disiapkan untuk tugas tersebut.

Setelah proses pengisian identitas maka waktu mengerjakan soal dimulai. Perangkat soal yang telah diprogramkan dapat dibuka peserta ujian setelah membuka token (semacam sandi pembuka) yang diberikan oleh proktor yang ada di setiap satuan pendidikan. Materi ujian dapat muncul di layar komputer dan setiap peserta ujian akan menerima materi soal yang berbeda dengan jumlah soal yang sama. Para peserta ujian diminta untuk mengerjakan soal yang muncul satu soal yang disusul dengan soal lainnya tanpa memperhitungkan tingkat kesukaran soal dan kemampuan peserta sebagaimana yang berlaku dalam CAT. Peserta ujian diminta memilih alternatif jawaban yang disediakan sehingga peserta ujian tidak perlu kuatir tentang teknik menghitamkan sebagaimana ujian tertulis. Hal ini mengurangi tingkat kecemasan peserta ujian dan bila peserta sudah selesai mengerjakan seluruh soal yang diperuntukkan untuk seorang peserta ujian, yang bersangkutan dapat memeriksa atau memperbaiki pekerjaan yang dilakukan sebelumnya selama waktu mengerjakan masih ada/tersedia dan hal ini tidak berlaku dengan model CAT. Oleh karena itu Model UNBK ini yang dipilih karena lebih mendekati pelaksanaan ujian tertulis sedang dalam model CAT peserta ujian tidak dapat melihat kembali soal yang telah dikerjakan.

Pelaksanaan UNBK masih bersifat offline untuk setiap satuan pendidikan yang telah ditetapkan sebagai penyelenggara ujian. Hal itu dipilih didasarkan pada kekhawatiran adanya kendala dalam pelaksanaan sehingga bila ada kendala dapat dikendalikan secara lokal dan proses ujian dapat berlangsung dengan baik. Bahan ujian dalam perangkat lunak disiapkan untuk setiap satuan pendidikan penyelenggara dan bahan ujian tersebut sama untuk setiap provinsi. Bahan ujian untuk UNBK dibagi dalam tiga zona yaitu Indonesia Timur, Indonesia Tengah, dan Indonesia Barat. Oleh karena itu, bahan ujian yang digunakan di setiap provinsi dalam suatu zona adalah setara, serta bahan tersebut dimasukkan dalam perangkat lunak UNBK. Dalam penyelenggaraan UNBK di suatu sekolah terdiri atas beberapa ruang ujian sehingga diperlukan jaringan lokal antarruang ujian. Perangkat lunak yang memuat bahan ujian disiapkan satu dan bahan tersebut direkam pada server di tingkat satuan pendidikan. Dari server inilah dibagikan atau disebarkan bahan ujian untuk setiap peserta ujian di ruang ujian yang berbeda melalui jaringan lokal. Pengendali bahan ujian di sekolah dilakukan oleh teknisi yang telah dilatih atau dipersiapkan. Hasil ujian yang terekam dalam server satuan pendidikan dapat dikirimkan langsung pada server Panitia Tingkat Pusat yaitu Puspendik. Hasil tersebut dapat dipindai secara otomatis melalui program yang telah dikembangkan oleh Puspendik serta hasil tersebut akan dipadukan dengan hasil ujian yang dilakukan secara tertulis. Proses-proses tersebut menyebabkan hasil ujian nasional tidak segera didapatkan peserta ujian sementara mereka dituntut untuk menyiapkan diri untuk melanjutkan sekolah (khusus SMA) atau mencari pekerjaan (khusus SMK) sehingga ada sebagian yang meninggalkan lokasi sekolahnya ke daerah lain dan hal itu akan menyulitkan mereka untuk memeroleh sertifikat dan ijazah.

Pada dasarnya, pelaksanaan ujian model ujian offline satuan pendidikan dapat ditingkatkan menjadi ujian offline yang meliputi wilayah yang lebih luas. Pada awalnya ujian dapat dilakukan secara rayon dan selanjutnya dilakukan hingga tingkat kabupaten/kota atau provinsi. Pengalaman dan kendala pada pelaksanaan ujian offline pada satuan pendidikan dijadikan dasar untuk pengembangan ujian offline ke wilayah lebih lanjut. Untuk itu, diperlukan skema pengembangan pelaksanaan UNBK masa depan. Pelaksanaan ujian offline secara rayon menjadi tingkat kabupaten/kota menjadi UNBK online pada tingkat kabupaten/ kota. Jika ujian secara online dilaksanakan pada kabupaten/kota maka penyiapan bahan ujian yang dikirimkan pada kabupaten/kota akan 
semakin berkurang dibandingkan dengan satuan pendidikan. Penyelenggaraan ujian online pada tingkat kabupaten/kota ditingkatkan menjadi tingkat provinsi hingga nasional dilakukan secara langsung.

Dalam proses pelaksanaan UNBK di setiap satuan pendidikan terdapat satu orang teknisi dan setiap ruang ujian terdapat dua orang petugas yaitu proktor dan pengawas. Teknisi merupakan petugas yang mengawasi perangkat keras maupun aplikasi UNBK di tingkat satuan pendidikan. Proktor bertugas untuk mengawasi pelaksanaan ujian di dalam ruang ujian dan melaporkan rintangan yang dihadapi peserta ujian dalam hal perangkat lunak atau aplikasi. Tugas utama proktor adalah menjamin seluruh komputer dapat digunakan dalam pelaksanaan UNBK, sedangkan teknisi bertugas memastikan perangkat keras yang diperlukan dalam UNBK telah tersedia dan dapat digunakan sebagaimana mestinya. Proktor dan teknisi adalah petugas yang melancarkan pelaksanaan UNBK. Pengawas bertugas mengawasi kelancaran pelaksanaan ujian di satu ruang ujian. Dalam pelaksanaan ujian tertulis hanya ada dua orang yang bertugas di satu ruang ujian sebagai pengawas kelancaran pelaksanaan ujian, serta ada satu orang pengawas satuan pendidikan. Data tenaga proktor dan teknisi dalam pelaksanaan UNBK 2015 yang diperoleh dari Puspendik berjumlah 1556 orang proktor dan teknisi 1338 orang yang bertugas di 556 satuan pendidikan. Jumlah petugas tersebut akan meningkat seiring dengan peningkatan jumlah satuan pendidikan yang melaksanakan UNBK di masa mendatang.

\section{Model UNBK}

Pelaksanaan UNBK secara offline diharapkan menjadi dasar untuk model pengembangan pelaksanaan UNBK lebih lanjut atau masa depan. Model UNBK masa depan merupakan pelaksanaan ujian nasional secara langsung melalui bantuan internet sehingga ujian nasional dapat dilaksanakan secara online mulai dari tingkat kabupaten/kota, provinsi hingga nasional. Proses UNBK dilakukan secara langsung dan bertahap dalam lingkup kabupaten/kota kemudian lingkup provinsi ataupun nasional sesuai dengan dukungan perkembangan sarana internet. Dewasa ini, dukungan internet dalam proses komunikasi di Indonesia sudah cukup memadai terutama untuk daerah perkotaan, sedang untuk daerah pedesaan masih sulit atau terbatas. Perkembangan teknologi terbaru adalah adanya Baloon Google yang dapat menghadirkan akses internet di daerah pedalaman (Kompas, 2015). Baloon Google (Project Loon) merupakan balon raksasa yang diterbangkan di atas permukaan bumi sekitar $18 \mathrm{~km}$ yang memudahkan akses internet dan diperuntukkan bagi wilayah Indonesia yang belum terjangkau internet dan infrastruktur telekomunikasi. Model teknologi Baloon Google telah dikembangkan oleh pemerintah dan swasta mulai tahun 2016 sehingga seluruh wilayah pedalaman dapat dijangkau akses internet. Dengan demikian, pelaksanaan UNBK secara langsung melalui internet merupakan solusi pelaksanaan ujian nasional di daerah terpencil atau tertinggal atau daerah pedalaman.

Model pelaksanaan UNBK ujian secara langsung atau tidak langsung memberi keuntungan antara lain menghemat biaya penggandaan, memudahkan distribusi bahan, mudah menjangkau seluruh wilayah, keamanan, mudah proses skoring dan memudahkan mencetak sertifikat hasil ujian nasional. Keuntungan ini diperoleh dengan membandingkan proses pelaksanaan ujian nasional tertulis seperti yang dilakukan selama ini. Penghematan dalam penggandaan naskah ujian karena proses tersebut tidak dilakukan jika menggunakan UNBK. Sebagaimana diketahui dalam proses pelaksanaan ujian tertulis pencetakan bahan ujian dilakukan setiap tahun, sedangkan bila dilakukan secara langsung (online) atau tidak langsung (offline) yang diperlukan adalah pengadaan perangkat keras (komputer) pada tahun pertama dan pada tahun-tahun berikutnya biaya pengadaan perangkat keras dapat berkurang atau hilang sama sekali. Bahkan biaya pengadaan ini dapat dilakukan oleh satuan 
pendidikan tanpa mengaitkannya dengan pelaksanaan ujian nasional. Pengadaan dikaitkan dalam rangka peningkatan pembelajaran atau pengadaan fasilitas sekolah sehingga biaya pengadaan perangkat keras semakin berkurang. Sebagaimana dijelaskan dalam uraian-uraian sebelumnya, dapat disimpulkan betapa urgen pembelajaran dengan pemanfaatan TIK.

Kemudahan dalam proses distribusi bahan ujian melalui UNBK terjadi karena proses distribusi bahan dapat dilakukan secara sederhana yaitu melalui internet dari pusat langsung ke satuan pendidikan penyelenggara ujian. Bila pelaksanaan UNBK dilakukan secara online dapat memangkas biaya distribusi serta biaya pengamanan bahan ujian selama dan sebelum pelaksanaan ujian. Proses-proses dalam ujian tertulis memerlukan biaya yang sangat besar sedang bila dilaksanakan secara online dan offline maka biaya distribusi relatif lebih murah dibandingkan dengan secara tertulis. Bila terjadi kecurangan atau kejadian yang menyebabkan kerusakan bahan ujian maka dengan mudah dapat dikirimkan ke lokasi tempat permasalahan itu terjadi. Pendistribusian bahan ujian mudah dilakukan karena menggunakan internet sehingga tidak memerlukan tenaga keamanan yang banyak dalam distribusi dan pengamanan mudah dilakukan dengan penggunaan sandi pengguna dan sandi pembuka dalam file soal yang dikirimkan.

Wilayah Indonesia terdiri atas kepulauan dan tersebar di wilayah pedalaman sehingga sulit dijangkau dengan menggunakan sarana transportasi seperti selama ini. Proses pendistribusian bahan ujian rumit karena luas wilayah dan keterbatasan sarana pengangkutan. Melalui model UNBK masa depan pendistribusian pada wilayah yang luas dapat dilakukan dengan mudah serta dijangkau melalui internet. Dengan menggunakan sarana internet ditambah dengan penggunaan teknologi Baloon Google seluruh pelosok tanah air dapat terjangkau. Kemudahan menjangkau seluruh wilayah sehingga dapat mengurangi kesalahan dalam distribusi bahan ujian. Pendistribusian bahan ujian melalui internet mudah menjangkau seluruh wilayah walaupun di wilayah tersebut sulit transportasi. Melalui kemajuan teknologi internet maka wilayah terpencil atau terpinggir mudah dijangkau dalam distribusi bahan dan pengiriman hasil dapat dilakukan dengan cepat. Kemudahan dalam proses distribusi bahan akan dapat meningkatkan kualitas pelaksanaan UNBK karena para pemangku kepentingan dapat menyiapkan pelaksanaan UNBK secara baik dan tidak perlu ada kekhawatiran bahan belum diterima pada waktu proses pelaksanaan.

Aspek keamanan dalam penyelenggaraan ujian nasional merupakan aspek yang turut memengaruhi kualitas pelaksanaan ujian. Aspek keamanan meliputi keamanan dalam proses penyiapan bahan, penggandaan naskah, pendistribusian bahan ujian. Aspek keamanan dalam penyelenggaraan ujian nasional merupakan aspek yang turut memengaruhi kualitas pelaksanaan ujian. Keamanan dalam proses penyiapan bahan tetap ada baik secara tertulis maupun dengan UNBK masa depan. Keamanan dalam proses penggandaan naskah sangat penting karena naskah ujian dicetak oleh perusahaan percetakan yang melibatkan banyak orang. Dalam proses penggandaan selama ini sering ada oknum yang membocorkan dan hal ini kurang baik dalam pelaksanaan ujian nasional. Demikian pula dalam proses pendistribusian bahan ujian hingga ke tempat penyimpanan bahan terakhir sangat rawan kebocoran sehingga perlu melibatkan tenaga keamanan yang banyak. Melalui UNBK, hal tersebut dapat dikurangi karena penggandaan bahan ujian dapat dilakukan terpusat secara online. Demikian pula dalam proses pendistribusian bahan dapat dilakukan dengan mudah dan dilakukan secara langsung melalui jaringan internet. Yang perlu diperhatikan adalah keamanan dalam jaringan komputer dari serbuan peretas atau hacker. Untuk itu, perlu dilakukan pengamanan berlapis dalam jaringan komputer yang ada. 
Proses skoring selama ini dilakukan di tingkat pusat sehingga laporan hasil ujian nasional memerlukan waktu lama. Melalui penggunaan internet atau UNBK masa depan, proses itu dapat dilalui tanpa harus menunggu hasil dari tingkat pusat. Pada perangkat soal (aplikasi) yang digunakan dalam UNBK telah disertakan kunci jawaban dan prosedur penskoran. Setelah peserta ujian selesai ujian maka hasilnya dapat segera diketahui. Bila hasil capaian peserta ujian belum memenuhi kriteria yang ditentukan maka peserta tersebut dapat dijadwalkan ulang untuk mengikuti ujian nasional susulan atau perbaikan. Bagi peserta didik yang sudah selesai mengikuti UNBK dan hasilnya memenuhi kriteria yang ditentukan, mereka dapat memroses hasil tersebut lebih lanjut untuk memeroleh sertifikat hasil ujian nasional. Untuk itu, dalam program atau perangkat lunak atau aplikasi UNBK telah disiapkan format tentang sertifikat hasil ujian nasional. Agar tidak terjadi kecurangan maka dalam perangkat lunak atau aplikasi UNBK diberikan sandi pengguna dan sandi pembuka untuk setiap satuan pendidikan. Demikian juga satuan pendidikan yang menerapkan sistem kredit semester sesuai Kurikulum 2013 dapat terbantu dengan penerapan UNBK masa depan. Peserta didik dapat mengikuti ujian nasional setelah proses pembelajaran yang dibebankan diselesaikan dengan baik. Model UNBK ini dapat diselenggarakan dua kali dalam setahun sehingga peserta didik khususnya SMA dapat melanjutkan pendidikan ke jenjang lebih tinggi sesuai dengan kemampuan peserta didik. Untuk itu, hasil UNBK dapat diintegrasikan pada sistem penerimaan mahasiswa baru untuk perguruan tinggi negeri.

\section{Hambatan Pelaksanaan UNBK}

Hambatan utama dalam pelaksanaan UNBK antara lain wilayah Indonesia yang luas, penyiapan perangkat keras, sarana internet, dan dukungan para pemangku kepentingan. Faktor-faktor ini yang menghambat pelaksanaan UNBK. Seperti kita pahami, Indonesia yang memiliki ribuan pulau dan wilayah yang sangat luas serta sebagian sulit dijangkau melalui transportasi darat, laut, maupun udara. Wilayah yang sangat luas dan terpencil menjadi hambatan utama dalam pelaksanaan ujian nasional terutama karena minimnya sarana infrastruktur. Sulitnya menjangkau wilayah pedalaman menjadi alasan untuk tidak menerapkan UNBK. Wilayah yang sangat luas dengan tingkat kemajuan yang berbeda-beda antarwilayah membuat para pemangku kepentingan resisten atau menolak pelaksanaan UNBK.

Penyediaan perangkat keras seperti komputer dengan jumlah besar atau sesuai dengan jumlah peserta ujian sangat diperlukan. Walaupun satu komputer dapat digunakan oleh tiga orang dalam satu hari ujian. Untuk penyediaan perangkat keras sesuai jumlah peserta ujian memerlukan biaya besar. Besarnya biaya penyediaan perangkat ini menjadi alasan satuan pendidikan atau pemangku kepentingan untuk menolak UNBK diterapkan di suatu sekolah atau wilayah. Pengadaan komputer ini, pada dasarnya dibutuhkan juga untuk proses pembelajaran artinya komputer tidak hanya digunakan untuk UNBK tetapi juga untuk pembelajaran. Oleh karena itu, upaya untuk penyiapan perangkat keras (komputer) ini merupakan keharusan untuk meningkatkan mutu pembelajaran di satuan pendidikan. Untuk itu, perlu diupayakan adanya jaringan komputer di tiap satuan pendidikan agar hasil pembelajaran atau kompetensi peserta didik meningkat dalam rangka menghadapi kehidupan global.

Sarana internet merupakan sarana pendukung utama dalam pelaksanaan UNBK (langsung-online), sedang dengan model offline, internet merupakan penunjang saja. Dalam pelaksanaan UNBK, keberadaan internet merupakan yang utama dan semakin besar kapasitas internet menyebabkan UNBK secara langsung dapat dilakukan sehingga mengurangi biaya-biaya yang dibutuhkan seperti model PBT. Kapasitas internet yang besar dan lancar memudahkan UNBK secara langsung yaitu perangkat soal ada di tingkat pusat. Artinya, peserta di sekolah langsung menghadap 
komputer dan soal hadir dihadapan peserta ujian secara langsung. Pemahaman masyarakat tentang internet merupakan suatu yang mahal sehingga penerapan UNBK ini semakin sulit. Penyediaan internet di satuan pendidikan sebenarnya mudah dilakukan yaitu dengan mengadakan kerja sama dengan provider atau penyedia jaringan internet dan para pengguna membayar internet sesuai dengan apa yang digunakannya. Model seperti ini sudah banyak dilakukan oleh satuan pendidikan di kota-kota besar sehingga pelaksanaan UNBK berbasis kota memungkinkan dilaksanakan.

Dukungan pemangku kepentingan seperti kepala sekolah dan pejabat dinas pendidikan terhadap pelaksanaan UNBK sangat menentukan dalam penerapan UNBK. Para pemangku kepentingan yang belum memahami atau menyadari keuntungan pelaksanaan UNBK cenderung untuk menolak pelaksanaan UNBK. Para pemangku kepentingan cenderung konservatif dalam penerapan UNBK tersebut. Bila pemangku kepentingan merasa keberatan dalam penerapan UNBK maka upaya-upaya untuk penerapan UNBK ditolak. Bagi pemangku kepentingan yang memberi tanggapan yang tinggi atau positif, mereka cenderung untuk menyiapkan dan mendorong satuan pendidikan menerapkan UNBK serta melengkapi perangkat keras yang diperlukan dalam pelaksanaan UNBK.

\section{SIMPULAN DAN SARAN}

\section{Simpulan}

Dari hasil kajian pelaksanaan UNBK, dapat disimpulkan bahwa: 1) Pelaksanaan ujian nasional berbasis komputer telah berhasil dilaksanakan di 556 sekolah (SMP/MTs, 42, SMA/MA, 135, SMK 379) di 141 kabupaten/kota dan 30 provinsi serta dua sekolah Indonesia di luar negeri; 2) Pada awalnya, ujian berbasis komputer dikembangkan berdasarkan pendekatan CAT namun karena satuan pendidikan masih sebagian besar menggunakan ujian tertulis maka dipilih pendekatan CBT yang mendekati pelaksanaan model tertulis; 3 ) Penerapan sistem UNBK masa depan menghemat biaya penggandaan, memudahkan distribusi bahan, mudah menjangkau seluruh wilayah, mudah proses skoring dan mencetak sertifikat hasil ujian nasional, peserta didik dengan sistem kredit semester dapat mengikuti ujian nasional setelah menyelesaikan beban tugas semester, dan hasil UNBK dapat segera dikirimkan ke perguruan tinggi untuk digunakan sebagai salah satu alat seleksi masuk ke perguruan tinggi; dan 4). Hambatan dalam pelaksanaan UNBK adalah wilayah Indonesia yang luas, keterbatasan perangkat keras, sarana internet, dan dukungan pemangku kepentingan.

\section{Saran}

Pelaksanaan UNBK masih terbatas pada sejumlah sekolah maka disarankan: 1) sosialisasi pelaksanaan UNBK dilakukan secara intensif ke dinas pendidikan, satuan pendidikan, dan/atau melalui media massa; 2) UNBK dilaksanakan dengan pendekatan $C A T$; 3) dalam perangkat lunak atau aplikasi UNBK dimasukkan program skoring agar hasil UNBK dapat diketahui peserta ujian secara langsung dan hasilnya dicetak sehingga peserta ujian dapat segera mengetahui hasil dan memeroleh sertifikat; 4) pengadaan perangkat keras disediakan pemerintah untuk seluruh satuan pendidikan; dan 5) UNBK dilakukan secara langsung di lingkup kabupaten/ kota dilanjutkan ke provinsi atau nasional.

\section{PUSTAKA ACUAN}

Abdullah, S. 2009. Pemanfaatan Teknologi Informasi Untuk Mencapai Standar Proses Pembelajaran Matematika. Fasilitator (4), hlm 43-47.

Bagus, H. C. 2012. Administrasi Ujian Nasional (UN) Dengan Menggunakan Model Camputerized Adaptive Testing (CAT). Jurnal Pendidikan dan Kebudayaan 18(1), hlm. 45-53.

Bagus, H. C. 2013. Computerized Adaptive Testing (CAT) Salah Satu Alternatif Pengganti Paper 
Based Test (PBT). Value Jurnal Evaluasi \& Asesmen Pendidikan II (01), hlm. 60-72. Basuki, I. \& Hariyanto. 2014. Asesmen Pembelajaran. Bandung: Remaja Rosdakarya.

Bennet, R. E. \& Gitomer, D.H. 2009. Transforming K-12 Assessment: Integrating Accountability Testing, Formative Assessment and Profesional Support In C. Wyat-Smith \& J.J. Cumming (Eds). Educational Assessment in the 21st Century: Connecting Theory and Practice. London: Springer.

Badan Standar Nasional Pendidikan. 2015. Prosedur Operasional Standar Penyelenggaraan Ujian Nasional Tahun Pelajaran 2014/2015. Jakarta: Badan Standar Nasional Pendidikan.

Darmawan, D. \& Siti, H. D. 2014. Pengembangan E-Learning Berbasis Mooddle dan Facebook pada mata pelajaran TIK. Jurnal Teknodik 18(3), hlm. 227-240.

Evranita, S.P. 2009. Pemanfaatan Teknologi Di Sekolah Dasar. Fasilitator (4), hlm. 27-33.

Gregory. R. J., 2013. Tes Psikologi Sejarah, Prinsip, dan Aplikasi Edisi Keenam Jilid 2. Jakarta: Penerbit Erlangga.

Hadiana, D. 2015. Penilaian Hasil Belajar Untuk Siswa Sekolah Dasar. Jurnal Pendidikan dan Kebudayaan 21 (1), hlm. 15-25.

Kompas. 3 November 2015. Teras Kita Orang Kita di Jantung Google. hlm. 26.

Kusnohadi. 2014. Pendidik Online: Perluasan Tugas Dari Kelas Konvensional Menuju Kelas Maya. Jurnal Teknodik 18 (3), hlm. 333-350.

Luecht, R. M., \& Sireci, S. G. 2011. A Review of Models for Computer-Based Testing. College Board.

Muslich, M. 2011. Autentic Assessment: Penilaian Berbasis Kelas dan Kompetensi. Bandung: Refika Atif.

Nurchaili. 2010. Pengaruh Media Pembelajaran Berbasis Teknologi Informasi Dalam Proses Pembelajaran Kimia Terhadap Hasil Belajar Siswa. Jurnal Pendidikan dan Kebudayaan 16 (6), hlm. 648-658.

Nitko, A. J. \& Susan, M. B. 2011. Educational Assessment of Students (Sixth Edition). Boston, M.A: Pearson Education Inc., publishing as Allyn \& Bacon.

Peraturan Menteri Pendidikan dan Kebudayaan Nomor 5 Tahun 2015 tentang Kriteria Kelulusan Peserta Didik, Penyelenggaraan Ujian Nasional, Dan Penyelenggaraan Ujian Sekolah/ Madrasah/Pendidikan Kesetaraan Pada SMP/MTs Atau Yang Sederajat Dan SMA/MA/SMK Atau Yang Sederajat.

Purwanto. 2004. Pembelajaran Berbasis Teknologi Komunikasi dan Informasi Dalam Rangka Mewujudkan Keunggulan Proses Belajar Jurnal Teknodik Nomor 15(VIII), hlm. 23-41.

Pusat Penilaian Pendidikan. 2008. Berita, Buletin Puspendik Jembatan Informasi Pusat Penilaian Pendidikan, 5(1) hlm. 15.

Raco. 2010. Metode Penelitian Kualitatif, Jenis, Karakteristik, dan Keunggulannya. Jakarta: Gramedia Widyasarana Indonesia.

Santosa, A. 2009. Computerized Adaptive Testing (CAT) untuk pengukuran hasil belajar mahasiswa unistersitas terbuka. Disertasi doktor, tidak diterbitkan. Universitas Negeri Yogyakarta.

Suprananto. 2012. Model Computerized Adaptive Test (CAT) Untuk Ujian Pendidikan Kesetaraan. Value Jurnal Evaluasi \& Asesmen Pendidikan. I(03), hlm. 1-36.

Silverius, S. 2010. Kontroversi Ujian Nasional Sepanjang Masa. Jurnal Pendidikan dan 
Kebudayaan 16(2) hlm. 194-205.

Tanrere, M. \& Sumiati, S. 2012. Pengembangan Media Chemo-Edutainment Melalui Softwere Macromedia Flash MX Pada pembelajaran IPA Kimia SMP. Jurnal Pendidikan dan Kebudayaan 18(2) hlm. 156-162.

Waldopo. 2011. Analisis Kebutuhan Terhadap Program Multi Media Interaktif Sebagai Media Pembelajaran Jurnal Pendidikan dan Kebudayaan 17(2), hlm. 244-253. 
Rogers Pakpahan, Model Ujian Nasional Berbasis Komputer: Manfaat dan Tantangan 